\title{
Katarzyna Leśniewska-Napierała
}

\section{Dzialalność organizacyjna mniejszości polskiej na Lotwie (dawne Inflanty Polskie)*}

Inflanty Polskie stanowią najbardziej zróżnicowany kulturowo region Łotwy. Działa tu wiele organizacji, starających się podtrzymać tradycje mniejszości narodowych. W artykule omówiono działalność organizacyjną mniejszości polskiej w Łatgalii. Ukazano także działalność oświatową Polaków w Republice Łotewskiej. W badaniach wykorzystano socjologiczną metodę wywiadów pogłębionych z liderami organizacji polskich. Celem wywiadów było poznanie opinii najaktywniejszej, a jednocześnie najbardziej kompetentnej grupy działaczy.

Słowa kluczowe: mniejszość narodowa, Polacy, oświata, działalność organizacyjna, Inflanty Polskie, Łotwa.

\section{Wprowadzenie}

Współcześnie w większości państw na świecie zamieszkują grupy osób, które nie identyfikują się z tzw. większością tworzącą dane państwo (Janusz 2011). W czasach nowożytnych problem mniejszości narodowych pojawił się już w imperium brytyjskim i osmańskim, a zbliżona mozaika etniczna panowała także w imperiach Habsburgów i Romanowów. Jednakże aż do XIX w. trudno jest mówić o funkcjonowaniu mniejszości narodowych. Dopiero wraz z kształtowaniem się nowoczesnych narodów pojawił się w Europie termin „mniejszość narodowa" (Budyta-Budzyńska 2010).

Polacy na Łotwie należą do historycznych mniejszości narodowych i są ściśle związani z jej historią, kulturą i tradycją (Jēkabsons 2013). Polacy żyjący nad Dźwiną są grupą autochtoniczną. Pozostają oni poza granicami kraju od czasów pierwszego rozbioru Polski, kiedy Katarzyna I dokonała aneksji tzw. Inflant Polskich (Kurczewski, Fuszara 2009). Z kolei Polacy na terenach łotewskich są przede wszystkim ludnością napływową, ale nie przybyłą z innego państwa. Są to głównie potomkowie ludności przemieszczającej się w obrębie państwa polskiego (Fuszara 2009).

* Artykuł powstał w ramach projektu, który został sfinansowany ze środków Narodowego Centrum Nauki na podstawie decyzji nr DEC-2011/01/N/HS4/02144. 


\section{Geneza i rozmieszczenie Polaków w kontekście ich działalności organizacyjnej na Lotwie do 1990 r.}

Pojawienie się Polaków na Łotwie wiązało się z oddaniem pod opiekę Zygmunta Augusta Księstwa Kurlandii i Semigalii (z Dyneburgiem), po sekularyzacji dóbr Zakonu Kawalerów Mieczowych w 1562 r. (Eberhardt 1998a, b, Runiewicz-Jasińska 2003). Część zachodnia tych ziem do 1795 r. pozostawała w związku lennym z Polską. Z kolei z Łatgalii oraz Liwonii utworzono Księstwo Jadźwińskie, które bezpośrednio weszło w skład państwa polskiego za czasów króla Zygmunta Augusta. Jedynie Ryga zachowała swoją niezależność do 1581 r., kiedy to Stefan Batory włączył ją w granice Polski (Jēkabsons 1993, Runiewicz-Jasińska 2003). Przyłączenie tych ziem do Rzeczypospolitej przyniosło konsekwencje nie tylko polityczne, ale i narodowościowe. Miejscowa szlachta, która była w większości pochodzenia niemieckiego, uzyskała przywileje polskie, i tym samym zaczęla ulegać stopniowej polonizacji. Z czasem potomkowie rodów niemieckich stali się nie tylko lojalni wobec Rzeczypospolitej, ale również przejęli język polski i stopniowo rozpoczęli wtapianie w społeczeństwo polskie (Eberhardt 1998a, b).

Czynnikiem, który odegrał najważniejszą rolę w kształtowaniu się oblicza etnicznego na tych terenach, była religia. Inflanty Polskie pozostały katolickie, co pozwoliło na umocnienie się wpływów języka i kultury polskiej oddziałującej zarówno na szlachtę, jak i ludność wiejską (Eberhardt 1998a, Kowalski 2013). Łatgalia z czasem stała się regionem Łotwy najściślej związanym z kulturą polską. Na jej terenie z czasem pojawiły się polskie wsie, głównie na skutek polonizacji wśród katolików pochodzenia białoruskiego i łotewskiego (Eberhardt 1998a, Durejko 2001). W drugiej połowie XVIII w. nastąpił rozwój polskiego szkolnictwa na Łotwie. Powstały wówczas, ufundowane przez rodzinę Platerów, szkoły w Krasławiu (Runiewicz-Jasińska 2003).

W 1721 r. Szwedzi stracili swoją część Inflant na rzecz Rosji, natomiast Inflanty Polskie po pierwszym rozbiorze w 1772 r. przyłączono do Cesarstwa Rosyjskiego. Mimo zaborów, w polskiej część Inflant do 1861 r. utrzymała się pańszczyzna. Ma to konsekwencje do czasów współczesnych, gdyż region „dawnych pałaców i biednej wsi” pozostaje wciąż jednym z bardziej zacofanych na Łotwie. W Polskich Inflantach pomimo represji i licznych prób rusyfikacji wyznaniem dominującym pozostał katolicyzm (Kurczewski, Fuszara 2009).

Włączenie Inflant do Cesarstwa Rosyjskiego zahamowało procesy polonizacyjne łatgalskiej wsi. Warto podkreślić, że pomimo to w XIX w. nad środkową Dźwiną (z dala od etnicznych ziem polskich) ukształtował się rozległy obszar, którego ludność wiejska nie tylko znała, ale i posługiwała się językiem polskim. 
Cały obszar historycznych Inflant Polskich odznaczał się wieloetnicznością i był zamieszkiwany przez: Łotyszy, Litwinów, Białorusinów, Rosjan oraz Polaków (Eberhardt 1998a).

Represje rosyjskie po stłumieniu powstania styczniowego w 1863 r. dotknęły również ludność Łatgalii. Wprowadzono zakaz druku w języku polskim, prześladowano księży i nauczycieli religii. $\mathrm{W}$ instytucjach publicznych wprowadzono nakaz posługiwania się językiem rosyjskim (Runiewicz-Jasińska 2003). W odwecie, w Łatgalii, Rosjanie wprowadzili m.in. zakaz nabywania nieruchomości bez zezwolenia gubernatora (Jēkabsons 1994a, Runiewicz-Jasińska 2003). Pod koniec XIX w. wielu Polaków osiedliło się w powiecie iłłuksztańskim, gdyż nie wprowadzono tam zakazu nabywania ziemi (Jēkabsons 2013). Od lat 40. XIX w. Polacy byli całkowicie pozbawieni polskiego szkolnictwa. Ze szkół w Łatgalii wycofano język polski, a jedynymi ośrodkami szerzącymi język ojczysty był Kościół katolicki (Runiewicz-Jasińska 2003).

W 1878 r. w Łatgalii powstało Rzymskokatolickie Towarzystwo Dobroczynności, którego głównym celem działalności było kształcenie i wychowanie młodzieży polskiej w szkołach parafialnych. Podjęte przedsięwzięcia przyczyniły się do zachowania języka polskiego w regionie (Frąckowiak-Karczewska 1993, Durejko 2001, Runiewicz-Jasińska 2003, Jēkabsons 2013).

Według danych pochodzących z rosyjskiego spisu powszechnego z 1897 r., na obszarze zbliżonym do dzisiejszej Łotwy odnotowano ok. 2 mln mieszkańców, z których blisko 65 tys. zadeklarowało język polski jako ojczysty (Eberhardt 1996, 1998a). Najbardziej polskim ośrodkiem na Łotwie był i jest Dyneburg stolica dawnych Inflant Polskich. Pod koniec XIX w. Polacy stanowili 16\% ludności miasta (Kurczewski, Fuszara 2009). Poza Dyneburgiem Polacy koncentrowali się przede wszystkim w Rydze - stolicy Łotwy - oraz w Rzeżycy i Lucynie, a także w Iłłukszcie (Eberhardt 1998a).

W wyniku rewolucji w 1905 r. ludność nierosyjska odzyskała prawo do nauki języków ojczystych. Na początku XX w. w Rydze powstało polskie 8-letnie koedukacyjne gimnazjum Emilii Lichtarowicz. Po polsku prowadzono zajęcia z historii, geografii, literatury oraz języka polskiego. Drugą szkołą nauczającą języka polskiego było ryskie żeńskie gimnazjum Anny Jastrzębskiej, ale językiem wykładowym był rosyjski (Frąckowiak-Karczewska 1993, Runiewicz-Jasińska 2003).

W 1906 r. w Rydze powstało Polskie Towarzystwo „Oświata”, którego głównym celem działalności było stworzenie polskiego systemu edukacji na Łotwie. Do wybuchu pierwszej wojny światowej sieć polskich organizacji funkcjonowała w Rydze, Dyneburgu i Lipawie (Jēkabsons 1994a, Runiewicz-Jasińska 2003). Wybuch pierwszej wojny światowej przyczynił się do rozproszenia Pola- 
ków na Łotwie, co doprowadziło do znacznego osłabienia działalności „Oświaty”, a w konsekwencji do jej zawieszenia aż do 1920 r. (Durejko 2001).

Po proklamacji państwa łotewskiego Polaków uznano na ludność autochtoniczną i uzyskali oni status mniejszości narodowej. Pierwsze kontakty międzypaństwowe pomiędzy Polską a Łotwą nawiązano w 1919 r. podczas konferencji pokojowej w Paryżu (Runiewicz-Jasińska 2003, Łach 2011). Pod względem liczebności Polacy stali się czwartą mniejszością Łotwy, po Rosjanach, Niemcach i Żydach (Jēkabsons 2013). Pod koniec 1919 r. Polska i Łotwa zawarly umowę o pomocy w sprawie oswobodzenia Łatgalii, zajmowanej przez wojska bolszewickie. Trzeciego stycznia 1920 r. rozpoczęto łotewsko-polską ofensywę, która mimo ogromnych strat po stronie polskiej zakończyła się sukcesem. Groby polskich żołnierzy poległych w tych walkach do dziś znajdują się m.in. w Dyneburgu i Krasławiu (Łossowski 1990a, Paluszyński 1999, 2011, Runiewicz-Jasińska 2003). Warto wspomnieć, że polscy działacze zajmowali niechętny stosunek do państwowości łotewskiej i sprzyjali przyłączeniu Łatgalii do Polski. Spowodowało to represje wobec Polaków, m.in. zaczęto zwalniać polskich kolejarzy (Užule 2003).

Po wyzwoleniu Inflant Polskich, strona łotewska starała się doprowadzić do ewakuacji wojsk polskich z Łatgalii i powiatu iłłuksztańskiego - najdalej na wschód wysuniętej części Kurlandii. W lipcu 1920 r. nastąpił odwrót oddziałów polskich, a powiat iłłuksztański szybko został zajęty przez wojska łotewskie. W okresie tym stronie polskiej zależało na poprawnych stosunkach i sojuszu wojskowym z Łotwą, nawet kosztem utraty ziem spornych. Po zajęciu Wileńszczyzny w październiku 1920 r., wojska gen. Lucjana Żeligowskiego skierowały się na północ, docierając aż do granic powiatu iłłuksztańskiego. Doprowadziło to do pogorszenia stosunków polsko-łotewskich, a działania wojsk polskich wzbudziły wiele podejrzeń Łotyszy. Relacje obu stron mogło poprawić jedynie uznanie niepodległości Łotwy de iure przez Polskę, które zostało wstrzymane do 1921 r., ze względu na oczekiwania na podobny gest Ententy (Łossowski 1990a, Byczkowski 1992).

Powstanie niepodległej Łotwy spowodowało zmianę statusu politycznego ludności polskiej na tym obszarze. $\mathrm{Z}$ obywateli cesarstwa rosyjskiego przekształcili się oni w obywateli niewielkiej republiki, która stopniowa zmierzała do osłabienia pozycji mniejszości narodowych (Eberhardt 1998a, Németh, Léphaft 2013). Pierwszy powojenny spis ludności wykazał spadek ogólnej liczby ludności o ok. 400 tys., co było spowodowane stratami wojennymi, ale również niedokładnością spisu przeprowadzanego w jeszcze niestabilnej sytuacji politycznej Łotwy (Eberhardt 1998a). 
W okresie międzywojennym reprezentanci mniejszości narodowych byli nieprzerwanie obecni w łotewskim sejmie. W 1922 r. Polacy wystartowali w wyborach $\mathrm{z}$ własną listą kandydatów i uzyskali jeden mandat, natomiast w każdych kolejnych wyborach mandat uzyskiwało dwóch Polaków. Warto wspomnieć, że siła mniejszości narodowych w łotewskim sejmie wahała się między wartościami $11 \%$ a $19 \%$ ogółu. Jednak była to tylko siła potencjalna, gdyż przedstawiciele mniejszości nie potrafili się porozumieć między sobą (Albin 1993).

W tym czasie powstało wiele polskich organizacji o różnorodnych typach działalności. Do najważniejszych można zaliczyć: Związek Polaków na Łotwie (ZPŁ), Polskie Zjednoczenie Narodowe na Łotwie, Ryski Związek Towarzystw Polskich, Katolickie Towarzystwo Muzyczne „Harfa” w Dyneburgu, Stowarzyszenie Polsko-Katolickie Młodzieży na Łotwie „Promień”, Związek Polskiej Młodzieży Katolickiej na Łotwie (Durejko 2001).

W latach 20. XX w. nastąpił intensywny rozwój życia kulturalnego Polaków w tym kraju. W 1922 r. w Dyneburgu powołano Związek Polaków na Łotwie. Główne cele związku obejmowały przede wszystkim obronę praw mniejszości narodowych na Łotwie, rozwój działalności oświatowej i kulturalnej łotewskich Polaków oraz zwiększanie świadomości narodowej (Biernat 2003). Zaczęła się ukazywać polska prasa, w tym: „Głos Polski” i „Tygodnik Polski” (Runiewicz-Jasińska 2003). W całym kraju funkcjonowało wówczas ok. 30 polskich towarzystw kulturalnych, w tym teatry i chóry. Aktywnie działały także organizacje młodzieżowe, w tym harcerstwo (Runiewicz-Jasińska 2003, Jēkabsons 1994b). Początkowo miało ono dużą autonomię i mogło prowadzić swoją działalność w języku polskim. Najintensywniejszy rozwój harcerstwa na Łotwie przypadł na lata 30., kiedy ograniczono dostęp do polskiego szkolnictwa. Harcerstwo wypełniło powstałą lukę w kształceniu młodzieży polskiej (Durejko 2001). W 1919 r. na Łotwie istniało 17 polskich szkół podstawowych, w $1921 \mathrm{r}$. funkcjonowało zaś już 27 podstawówek oraz trzy gimnazja; w 1930 r. liczba polskich szkół wzrosła do 35, jednak już od 1934 r. liczba placówek zaczęła spadać (Stradiņš, Grosvalds 1994, Stradiņš, Szymańska 1994, Runiewicz-Jasińska 2003).

Do 1934 r. praktycznie wszystkie mniejszości miały nieograniczoną swobodę w działalności społecznej, politycznej, oświatowej itp. Polacy, Rosjanie, Niemcy i Żydzi posiadali swoich przedstawicieli w parlamencie (Jēkabsons 2013). Jednak już na początku lat 30 . na Łotwie nasiliły się nastroje nacjonalistyczne. Po przewrocie państwowym w maju 1934 r., na skutek akcji paramilitarnej organizacji „Aizsarga” i wojska, zawieszono działalność sejmu, wdrożono ustrój rządów autorytarnych oraz rozpoczęto wprowadzać ograniczenia możliwości kultywowania tradycji mniejszości (Eberhardt 1998a, Kurczewski 2009, Jēkabsons 2013). 
W listopadzie 1939 r. władze łotewskie uznały, że państwo polskie przestało istnieć i nie nawiązały stosunków dyplomatycznych z polskimi władzami na uchodźctwie. W konsekwencji zamknięto polską ambasadę w Rydze i konsulaty w Lipawie i Dyneburgu (Eberhardt 1998a). Po wybuchu drugiej wojny światowej wiele polskich organizacji dostosowało charakter swojej działalności do zmieniającej się sytuacji. Zaczęto organizować pomoc uchodźcom wojennym, pomagano polskim żołnierzom w ucieczkach (Jēkabsons 2013).

W czerwcu 1940 r. rozpoczęla się okupacja Łotwy przez Armię Czerwoną, a już 5 sierpnia tego roku Łotwa została wcielona do ZSRR. Spowodowało to deportacje polskich żołnierzy, a represje dotknęły również ludność łotewską (Runiewicz-Jasińska 2003, Jēkabsons 2013, Łossowski 1990b). W ciągu kilku miesięcy zamknięto wszystkie organizacje mniejszości, natomiast szkoły zostały poddane rusyfikacji (Jēkabsons 2013).

W dniu 22 czerwca $1941 \mathrm{r}$. rozpoczął się atak hitlerowców na Łotwę. Niemcy witani byli jako wyzwoliciele, a miejscowa ludność była przekonana, że pomogą im w odzyskaniu niepodległości. Entuzjazm osłabł, gdy mieszkańcy zostali postawieni przed wyborem pomocy okupantowi lub - w przypadku sprzeciwu wysłania do obozów koncentracyjnych (Runiewicz-Jasińska 2003). W 1942 r. wydano rozkaz eliminacji wpływów polskich na Łotwie, Polaków zaś zaczęto traktować jak wrogów Niemców. Wydano zarządzenie, które nakazywało zwalnianie polskich urzędników (Jēkabsons 2011).

W 1943 r. na Łotwie przeprowadzono spis powszechny, który wykazał ponad 38 tys. osób narodowości polskiej. Liczba Polaków była znacząco niższa, w porównaniu z 1930 r., kiedy to spis wykazał blisko 49 tys. osób narodowości polskiej (Jēkabsons 2011). Aneksja państw bałtyckich do ZSRR w 1940 r. zakończyła okres niepodległej Łotwy. Podczas przynależności Łotwy do ZSRR przeprowadzono cztery spisy ludności $(1959,1970,1979,1989)$. Łotwa była bardzo zróżnicowana i odznaczała się niższym udziałem rdzennej ludności łotewskiej. Było to spowodowano przede wszystkim dużo większym napływem ludności rosyjskiej (wzrost udziału Rosjan z 10\% przed wojną do ponad 26\% w 1959 r.). Liczba ludności polskiej wynosiła ok. 60 tys. i utrzymywała się na stałym poziomie. Polacy stali się pod względem liczebności trzecią, po Rosjanach i Białorusinach, mniejszością na Łotwie (Eberhardt 1996). Co ciekawe, mimo strat wojennych oraz wielu czynników uniemożliwiających utrzymywanie tożsamości narodowej, liczba Polaków wzrosła. Największymi skupiskami Polaków była tradycyjnie Łatgalia z Dyneburgiem oraz stołeczna Ryga. Z kolei ostatni spis z czasów przynależności Łotwy do ZSRR z 1989 r. wykazał, że likwidacja polskich szkół doprowadziła do asymilacji językowej, zwłaszcza wśród młodego pokolenia. Spośród ponad 60 tys. grupy Polaków tylko blisko 
16,5 tys. zadeklarowało język polski jako ojczysty (Eberhardt 1998a, Németh 2013).

Po 1945 r. Polacy na Łotwie stracili praktycznie swój cały dorobek oświatowo-kulturalny. Utracili również status mniejszości narodowej (Runiewicz-Jasińska 2003). Przez ponad 50 lat władzy radzieckiej język polski można było usłyszeć praktycznie tylko w kościołach. Doprowadziło to do asymilacji językowej na wielką skalę (Biesiadowska 2004). Tuż po wojnie, w latach 1947-1949 dokonano likwidacji całego szkolnictwa polskiego. Zamknięto również wszystkie organizacje wspierające i promujące polskość na Łotwie. Polacy byli postrzegani przez nowe władze jako katolicy z antysowieckim nastawieniem. Rosjanie rozpoczęli także akcję prześladowań Kościoła katolickiego, przy jednoczesnej promocji laickiego światopoglądu (Biernat 2003, Eberhardt 2012). W tej sytuacji starsze pokolenie Polaków rozpoczęło tajne nauczanie języka polskiego. Nie zapobiegło to jednak wynarodowieniu, zwłaszcza młodego pokolenia Polaków. Dodatkowym czynnikiem wspomagającym ten proces był całkowity brak kontaktu z macierzą. Ludność polska na Łotwie była w wyjątkowo trudnej sytuacji, gdyż z powodu braku obywatelstwa polskiego nie została objęta umową repatriacyjną zawartą między Polską i ZSRR (Grędzik 1999).

Pierwsze symptomy odradzenia narodowego Polaków na Łotwie pojawiły się w latach 70. XX w., kiedy w Rydze powstał Klub Miłośników Kultury Polskiej, skupiający ponad 300 osób. W ramach klubu utworzono organizację kulturalno-oświatową „Polonez”. Podczas zebrań rozmawiano po polsku, zapraszano polskie teatry z Wilna i Lwowa, organizowano koncerty polskiej muzyki, a także organizowano akademie w święta narodowe (Grędzik 1999).

Polacy dobrze odnaleźli się w zmianach zachodzących pod koniec lat 80. XX w. i zaangażowali się w odbudowę tożsamości narodowej. W 1989 r. w Rydze nastąpiła reaktywacja Związku Polaków na Łotwie, a jego prezesem została Ita Kozakiewicz - działaczka na rzecz zbliżenia obydwu narodów. W 1990 r. istniało już dziewięć oddziałów, z najprężniej działającym dyneburskim oddziałem „Promień” (Jędrzejewski 1999).

Sytuacja mniejszości polskiej w okresie przynależności do ZSRR była nieporównywalnie gorsza niż w okresie międzywojennym. Pozbawienie Polaków instytucji oświatowych i kulturalnych doprowadziło do zepchnięcia polskości tylko do sfery życia rodzinnego (Biernat 2003). 


\section{Polska oświata na Kotwie}

W okresie przynależności Łotwy do ZSRR polskie szkolnictwo zostało praktycznie w całości zlikwidowane. Władze radzieckie, argumentując to brakiem chętnych do pobierania nauki w języku polskim, starały się nie dopuścić do wzmocnienia poczucia tożsamości wśród ludności polskiej na Łotwie. Możliwość nauki w języku polskim pojawiła się dopiero pod koniec lat 80. XX w., a odbudowa polskiego szkolnictwa spotkała się z dużym poparciem Łotyszy (Boroń 2011, Runiewicz-Jasińska 2003). W 1989 r., z inicjatywy Związku Polaków na Łotwie, w jednej ze szkół w Rydze utworzono klasę polską, którą w późniejszych latach przekształcono w pierwszą polską placówkę oświatową w niepodległej Łotwie. Pod koniec tego roku, 12 grudnia, doszło nawet do podpisania Porozumienia o współpracy między Ministerstwem Edukacji Narodowej PRL i Ministerstwem Edukacji Narodowej Łotewskiej SRR na lata 1989-1995. Strona łotewska zobowiązała się m.in. do udzielania pomocy w podnoszeniu poziomu nauczania języka polskiego oraz innych przedmiotów nauczanych w tym języku, przygotowania odpowiednich podręczników i pomocy metodycznych, a także pomocy w zatrudnianiu nauczycieli i wychowawców przedszkolnych (Runiewicz-Jasińska 2003).

W 1991 r. na Łotwie przyjęto Ustawę o nieograniczonym rozwoju oraz prawie grup narodowościowych i etnicznych do autonomii kulturowej, która gwarantowała przedstawicielom mniejszości równe prawa w życiu publicznym. Dokument zobowiązywał również łotewskie instytucje rządowe do materialnego wspierania organizacji mniejszości narodowych w dziedzinie szkolnictwa, kultury oraz języka. W latach 90. ubiegłego wieku Polska i Łotwa zawarły także szereg umów bilateralnych regulujących m.in. kwestie uznawalności świadectw, opracowywania podręczników dla polskich szkół na Łotwie, organizacji doskonalenia nauczycieli itp. (Runiewicz-Jasińska 2003).

Polskie szkolnictwo na Łotwie po 1991 r. przeżywało swój renesans. Odradzanie polskich szkół zostało zainicjowane w dwóch największych skupiskach ludności polskiej, tj. w Rydze i Dyneburgu, gdzie pierwsze polskie klasy zostały utworzone już w 1989 r., a od 1991 r. rozpoczęły działalność polskie szkoły. W mniejszych ośrodkach zaczęto tworzyć szkółki niedzielne, m.in. w Jełgawie, Windawie, Iłłukszcie, Krasławiu, Kiesi i Lipawie (Grędzik 1999, Runiewicz-Jasińska 2003).

W 1992 r. łotewskie Ministerstwo Oświaty i Nauki przyjęło koncepcję rozwoju oświaty grup narodowościowych i etnicznych, która dała możliwość organizacji szkół mniejszości narodowych oraz gwarantowała ich finansowanie. Od końca lat 90. XX w. można było zaobserwować tendencję do stopniowego 
zmniejszania możliwości używania języków mniejszości narodowych w oświacie na Łotwie. Pojawiły się nawet propozycje, by szkoły, w których prowadzone są zajęcia w językach mniejszości, przekształcić w placówki prywatne, nieotrzymujące dotacji państwowych. Powodem takich zachowań był przede wszystkim fakt, że w łotewskim systemie oświaty wciąż dominowały szkoły rosyjskie, a wielu nauczycieli pracujących w tych placówkach nie znało języka łotewskiego (Leśniewska-Napierała 2015, Urlińska 2007).

W 2015 r. na Łotwie funkcjonowało pięć placówek oświatowych z polskim językiem nauczania, z czego aż trzy z nich w Dyneburgu - największym skupisku Polaków na Łotwie. Po ponad 40-letniej przerwie, 1 września 1991 r. została powołana Polska Szkoła w Dyneburgu (Leśniewska 2014, Leśniewska-Napierała 2015). W 1993 r. szkoła odzyskała dawny budynek, a jego remont został sfinansowany ze środków ZPŁ (Runiewicz-Jasińska 2003). W 1998 r., w wyniku uzyskania akredytacji, placówka uzyskała status szkoły średniej. Od 2000 r. szkoła stała się właścicielem kolejnego budynku, dzięki czemu możliwe stało się utworzenie sali widowiskowej oraz sali gimnastycznej (Grędzik 1999).

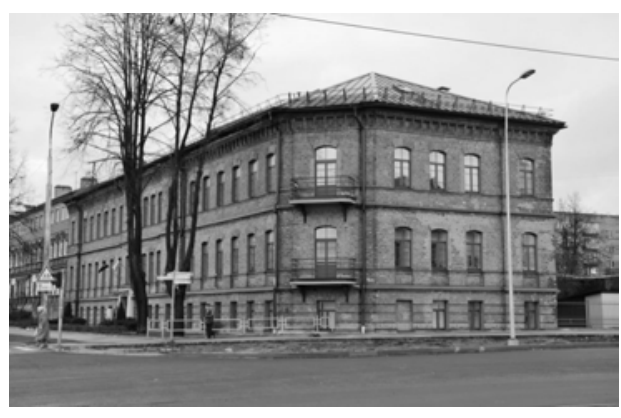

Ryc. 1. Polskie Gimnazjum im. Józefa Piłsudskiego w Dyneburgu Źródło: fot. K. Leśniewska

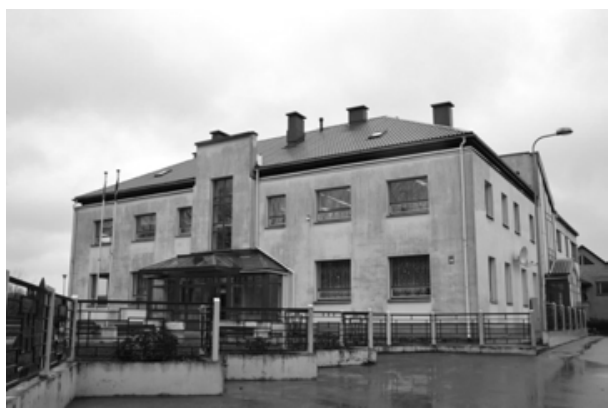

Ryc. 2. Polska Szkoła Podstawowa im. hr. Platerów w Krasławiu Źródło: fot. K. Leśniewska

We wrześniu 1991 r. swoją działalność rozpoczęła również Polska Szkoła Początkowa w Krasławiu. W roku szkolnym 1996/1997 placówka otrzymała status szkoły dziewięcioletniej, jednakże uzyskała negatywny wynik w postępowaniu akredytacyjnym. Powodem decyzji były nieprawidłowości w zarządzaniu placówką. Kolejna akredytacji w 1998 r. zakończyła się wynikiem pozytywnym (Grędzik 1999, Runiewicz-Jasińska 2003). W 2002 r. wybudowano nową siedzibę szkoły, która została w całości sfinansowana przez stronę polską. W styczniu 2016 r. na posiedzeniu rady okręgowej zapadła decyzja o zamknięciu placówki z powodu zbyt małej liczby uczniów. Rada zastrzegła jednak, że w przypadku uzyskania współfinansowania ze strony polskiej podjęta decyzja 
straci swoją ważność. Na skutek starań polskiego MSZ 24 lutego 2016 r. podpisano porozumienie o współpracy na rzecz funkcjonowania i rozwoju placówki, a styczniowa uchwała została anulowana ${ }^{1}$.

We wrześniu 1993 r. w Rzeżycy uruchomiono Polską Szkołę Początkową. która jednak w początkowych latach była źle wyposażona, brakowało podręczników i pomocy dydaktycznych. W 1997 r. placówce udało się zdobyć nowy, dużo większy budynek oraz akredytację łotewską i w 2000 r. przekształcono ją w Polską Szkołę Podstawową (Runiewicz-Jasińska 2003).

Od 1993 r. działa również jedyne samodzielne polskie przedszkole na Łotwie, mieszczące się w Dyneburgu. Zajęcia w grupach przedszkolnych odbywają się $\mathrm{w}$ języku polskim $\mathrm{i}$ łotewskim na podstawie programu nauczania dla mniejszości narodowych. Przedszkole przygotowuje dzieci do nauki w Polskim Gimnazjum (Leśniewska-Napierała 2015).

Rok później, od 1 września, działalność rozpoczęła Podstawowa Szkoła Polska w Jakubowie (Runiewicz-Jasińska 2003). W roku szkolnym 1995/1996 szkoła pozytywnie przeszła postępowanie akredytacyjne (Grędzik 1999). Jednak ze względu na niż demograficzny, w 2012 r. placówkę połączono ze szkołą łotewską.

Liczba uczniów w placówkach oświatowych z polskim językiem wykładowym na Łotwie od kilku lat utrzymuje się na stałym poziomie. Do szkół tych uczęszcza również młodzież innych narodowości, jednak zdecydowaną większość stanowią Polacy. Placówki polskie stawiają sobie za cel nauczanie języka polskiego oraz przekazywanie wiedzy z zakresu kultury, geografii i historii Polski. W placówkach z polskim językiem nauczania, w języku ojczystym prowadzone są zajęcia z literatury i nauki o języku, religii, historii Polski oraz zajęcia pozalekcyjne. Jak zauważa M. Stanisławska (2003), jest to zadanie bardzo trudne do zrealizowania, ze względu na to, że wiele dzieci w ogóle nie zna języka polskiego.

Od blisko 20 lat na Wydziale Humanistycznym Uniwersytetu w Dyneburgu odbywa się kształcenie na kierunku filologia polska. Zajęcia prowadzone są na poziomie studiów licencjackich, natomiast na poziomie studiów magisterskich istnieje możliwość wyboru specjalizacji „nauczanie języka polskiego”.

\footnotetext{
${ }^{1}$ Na podstawie badań własnych autorki.
} 


\section{Organizacje i stowarzyszenia polskie}

W czasach radzieckich jedyną polską organizacją funkcjonującą na Łotwie od końca lat 70. XX w. był Klub Kultury Polskiej „Polonez” przy Domu Kultury Budowniczych w Rydze. W połowie następnej dekady, na skutek zmian wprowadzanych w ZSRR przez Michaiła Gorbaczowa zmieniła się polityka wewnętrzna państwa, a tym samym sytuacja mniejszości polskiej na Łotwie (Grędzik 1999). Pod koniec 1988 r. powołano Stowarzyszenie Społeczno-Kulturalne Polaków na Łotwie (SSKPŁ). Na pierwszym zjeździe, który odbył się w styczniu 1990 r., stowarzyszenie to zostało przekształcone w Związek Polaków na Łotwie (ZPŁ) $)^{2}$. Odradzający się polski ruch narodowy znalazł odzwierciedlenie w szybko powstających oddziałach ZPŁ. Władze tego Związku zwracały szczególną uwagę na brak elit intelektualnych w środowisku polskim, spowodowany brakiem możliwości zdobycia odpowiedniego wykształcenia. Pierwszym działaniem, którego podjął się ZPŁ, było stworzenie odpowiednich warunków do kształcenia Polaków. Postarano się o stworzenie sieci placówek oświatowych z polskim językiem nauczania, a także wysyłano młodzież na studia do Polski (Jędrzejewski 1999).

Głównymi celami działalności ZPŁ stały się: integracja Polaków na Łotwie, odrodzenie szkolnictwa polskiego, odnowa życia religijnego oraz ochrona polskiego dziedzictwa na Łotwie ${ }^{3}$. W pierwszym roku działania ZPŁ powołał osiem oddziałów, w tym w: Dyneburgu, Krasławiu i Rzeżycy. W 2000 r. na Łotwie działało już 15 oddziałów ZPŁ, a nowe filie powstały w: Jakubowie, Kiesiu i Iłukszcie (Biernat 2003). Za cele na najbliższe lata działalności organizacja przyjęła wzmocnienie autorytetu Polaków na Łotwie, wspieranie dalszego rozwoju polskiego szkolnictwa, wsparcie polskiego biznesu oraz stworzenie portalu internetowego organizacji. Liderzy organizacji deklarują również podjąć starania, by język polski został uznany językiem regionalny w Łatgalii ${ }^{4}$.

W 1988 r. w Dyneburgu powstało Stowarzyszenie Kulturalno-Oświatowe „Promień”, którego głównym celem działalności był rozwój polskiej kultury i oświaty na Łotwie. W pierwszej kolejności rozpoczęto starania o utworzenie szkółki niedzielnej pozwalającej na nauczenie języka polskiego zarówno dzieci, jak i osób starszych (Jędrzejewski 1999). Po powstaniu ZPŁ Stowarzyszenie przekształciło się w jego oddział.

\footnotetext{
${ }^{2}$ W latach 1922-1934 i 1938-1939 działał Związek Polaków w Łotwie, za którego „spadkobiercę” w wielu opracowaniach uznaje się Związek Polaków na Łotwie.

${ }^{3}$ Na podstawie Statutu Związku Polaków na Łotwie (2005).

${ }^{4} \mathrm{Na}$ podstawie wywiadów z liderami ZPŁ.
} 
W 1997 r. w Dyneburgu powołano Centrum Kultury Polskiej (CKP), którego utworzenie zostało wsparte przez Urząd Miasta Dyneburg (Jędrzejewski 1999). Powstanie CKP było swego rodzaju wyrazem otwartości władz łotewskich na dążenia mniejszości polskiej do zachowania i pielęgnowania własnej tożsamości narodowej (Makowski 2009). Personalnie organizacja jest ściśle powiązana z dyneburskim oddziałem ZPŁ. Do najważniejszym celów działalności CKP można zaliczyć popularyzację wiedzy o polskiej kulturze i tradycjach ludowych. Centrum organizuje liczne imprezy o charakterze artystycznym, rozwija młode talenty, a także organizuje wiele konkursów, koncertów i festiwali. Dodatkowo CKP realizuje projekty wspólnie z polskimi szkołami na Łotwie i oddziałami ZPŁ. Przy Centrum Kultury Polskiej działają: kółko teatralne, zespół tańca ludowego „Kukułeczka”, zespól wokalny „Barwy Daugawy”, dziecięcy klub „Szkolna Chatka”, chór „Promień”, Klub Seniorów, Klub Polskich Kobiet i biblioteka 5 .

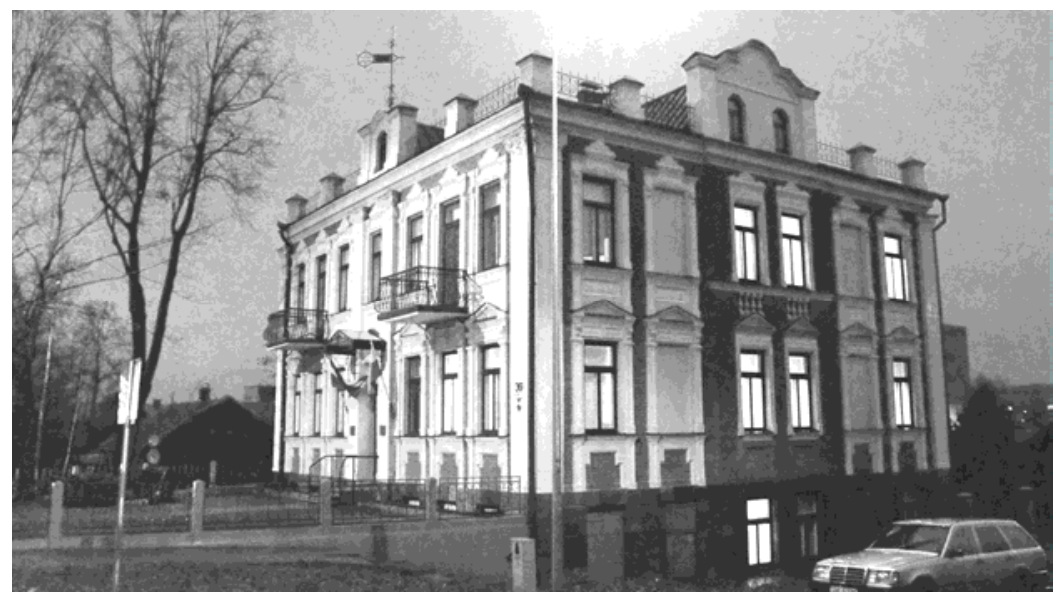

Ryc. 3. Centrum Kultury Polskiej w Dyneburgu Źródło: fot. K. Leśniewska

Od 2005 r. w Dyneburgu przy CKP działa Klub Stypendystów „Semper Polonia". Członkowie klubu skupiają się przede wszystkim na popularyzacji kultury polskiej wśród młodzieży, aktywnie uczestniczą w licznych przedsięwzięciach organizowanych przez CKP, opiekują się również grobami polskimi. Klub skupia przede wszystkim młodych Polaków studiujących w tym mieście.

W 2011 r. w Dyneburgu powołano również Stowarzyszenie „Odrodzenie Inflant”, prowadzące działalność o charakterze historyczno-kulturalnym. Inicjatorami działalności organizacji byli absolwenci filologii polskiej Uniwersytetu

\footnotetext{
${ }^{5} \mathrm{Na}$ podstawie wywiadów z liderami CKP i ZPŁ.
} 
Dyneburskiego. Stowarzyszenie planuje prowadzić badania naukowe w zakresie historii.

Według danych posiadanych przez Ambasadę RP w Rydze, w 2015 r. na Łotwie funkcjonowało 11 polskich organizacji społeczno-kulturalnych (tab. 1), a najważniejszą z nich był Związek Polaków na Łotwie, posiadający 15 oddziałów.

Tabela 1. Polskie organizacje zarejestrowane na Łotwie (stan na 2015 r.)

\begin{tabular}{|c|c|c|c|}
\hline Nazwa organizacji, siedziba & $\begin{array}{c}\text { Rok } \\
\text { założenia }\end{array}$ & \begin{tabular}{|c|} 
Wiodący charakter \\
działalności
\end{tabular} & Siedziba \\
\hline $\begin{array}{l}\text { Klub Kultury Polskiej } \\
\text { „Polonez” }\end{array}$ & 1978 & kulturalna & Slokas ielā 37, Ryga \\
\hline Związek Polaków na Łotwie & 1990 & kulturalna & $\begin{array}{l}\text { Varšavas ielā } 30, \\
\text { Dyneburg }\end{array}$ \\
\hline $\begin{array}{l}\text { Towarzystwo Dobroczynności } \\
\text { na Łotwie }\end{array}$ & 1991 & dobroczynna & $\begin{array}{l}\text { Krasotaju } 22 \text { m 12/1, } \\
\text { Ryga }\end{array}$ \\
\hline Liga Polskich Kobiet & 1995 & $\begin{array}{l}\text { dobroczynna, } \\
\text { kulturalna }\end{array}$ & Reņǵes ielā 5-3, Ryga \\
\hline $\begin{array}{l}\text { Centrum Kultury Polskiej } \\
\text { Klub Polskich Kobiet } \\
\text { Klub Seniorów }\end{array}$ & 1997 & $\begin{array}{l}\text { kulturalna, } \\
\text { oświatowa, } \\
\text { młodzieżowa }\end{array}$ & $\begin{array}{l}\text { Varšavas ielā 30, } \\
\text { Dyneburg }\end{array}$ \\
\hline $\begin{array}{l}\text { Związek Młodych Polaków na } \\
\text { Łotwie }\end{array}$ & 1998 & $\begin{array}{l}\text { młodzieżowa, } \\
\text { kulturalna }\end{array}$ & Ryga \\
\hline $\begin{array}{l}\text { Klub Stypendystów „Semper } \\
\text { Polonia” }\end{array}$ & 2005 & młodzieżowa & $\begin{array}{l}\text { Varšavas ielā } 30, \\
\text { Dyneburg }\end{array}$ \\
\hline $\begin{array}{l}\text { Stowarzyszenie „Odrodzenie } \\
\text { Inflant” }\end{array}$ & 2011 & $\begin{array}{l}\text { kulturalna, } \\
\text { naukowa }\end{array}$ & $\begin{array}{l}\text { Varšavas ielā } 30, \\
\text { Dyneburg }\end{array}$ \\
\hline $\begin{array}{l}\text { Asocjacja Dyrektorów Szkół } \\
\text { Polskich na Łotwie }\end{array}$ & $\mathrm{x}$ & $\begin{array}{l}\text { branżowa, } \\
\text { oświatowa }\end{array}$ & $\begin{array}{l}\text { Nīcgales ielā 15, } \\
\text { Ryga }\end{array}$ \\
\hline
\end{tabular}

Źródło: opracowanie własne na podstawie badań terenowych i danych Ambasady RP w Rydze.

Struktura przestrzenna organizacji polskich (ryc. 4) związana jest ściśle ze współczesnym rozmieszczeniem Polaków na Łotwie. Największa koncentracja siedzib organizacji lub ich oddziałów występuje w Dyneburgu oraz Rydze dwóch największych skupiskach ludności polskiej na Łotwie.

Polacy skupieni na obszarze dawnych Inflant Polskich wykazują się dużą aktywnością organizacyjną. Doprowadziło to m.in. do przeniesienia siedziby Związku Polaków na Łotwie do Centrum Kultury Polskiej w Dyneburgu. 
W ostatnich latach aktywność Polaków jednak wyraźnie spadła. Jak podkreślają liderzy polskich organizacji, powodem takiego stanu jest brak środków i odpowiedniego wsparcia ze strony władz polskich na realizację celów statutowych poszczególnych organizacji. Dodatkowo jako powody wymieniano również konflikty wewnętrzne $\mathrm{w}$ organizacjach, brak przepływu informacji na temat podejmowanych przedsięwzięć, a także brak zainteresowania organizacjami ze strony młodego pokolenia Polaków ${ }^{6}$.

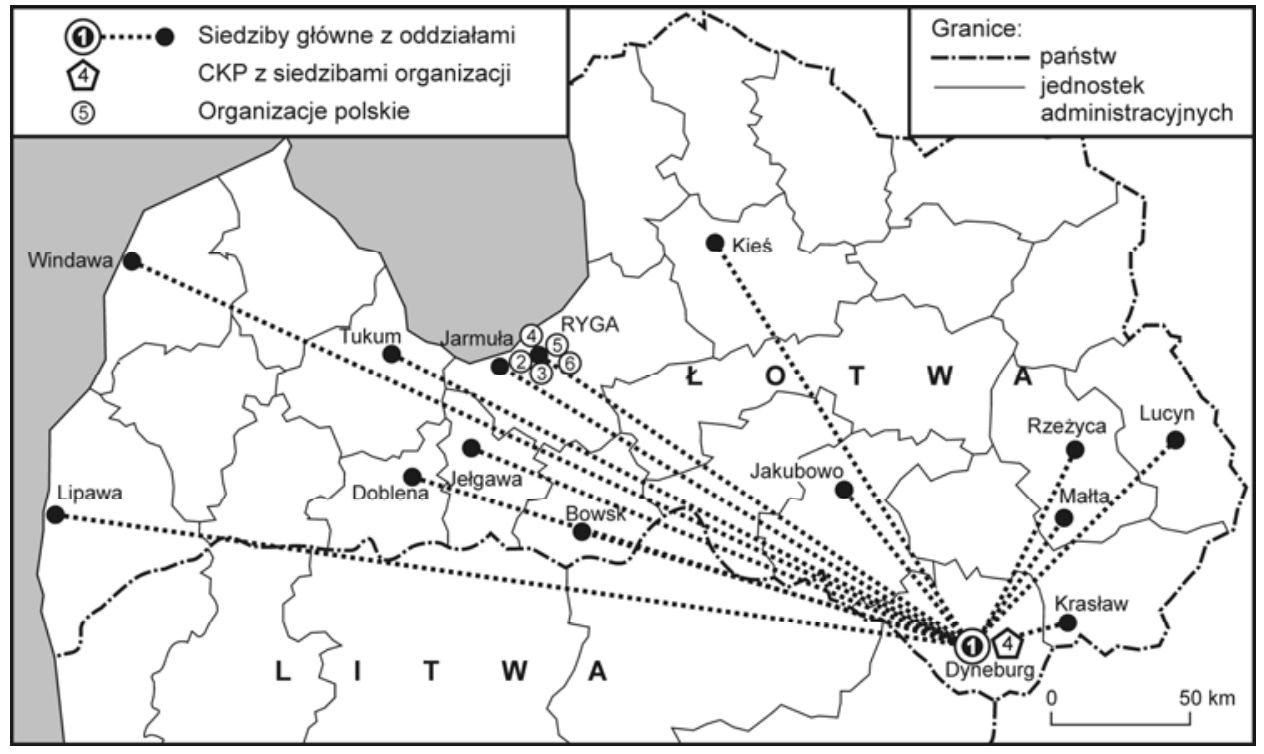

Ryc. 4. Struktura przestrzenna organizacji polskich na Łotwie w $2013 \mathrm{r}$.

Źródło: opracowanie własne na podstawie badań terenowych i danych Ambasady RP w Rydze

1 - ZPŁ; 2 - Klub Kultury Polskiej „Polonez”; 3 - Towarzystwo Dobroczynności na Łotwie; 4 - Liga Polskich Kobiet; 5 - Asocjacja Dyrektorów Szkół Polskich na Łotwie;

6 - Związek Młodych Polaków na Łotwie; CKP (z siedzibami organizacji:

Klub Polskich Kobiet, Klub Seniorów, Klub Stypendystów „Semper Polonia”, Stowarzyszenie „Odrodzenie Inflant”

Wśród Polaków na Łotwie bardzo ważną rolę odgrywa Kościół katolicki, który po wielu latach zniewolenia oraz represji zaczął się odradzać wraz z odzyskaniem przez Łotwę niepodległości (Jędrzejewski 1999). Polacy na Łotwie cechują się silną religijnością, stąd jest zapotrzebowanie na msze w języku polskim. Dodatkowo osoby starsze często traktują uczestnictwo w mszy w języ-

\footnotetext{
${ }^{6} \mathrm{Na}$ podstawie wywiadów z liderami polskich organizacji na Łotwie.
} 
ku polskim jako okazję do spotkań towarzyskich (Gawkowska 2009). W 2015 r. na Łotwie funkcjonowało ponad 20 kościołów z mszami w języku polskim (ryc. 5), w tym najwięcej w Łatgalii. Posługa duszpasterska w języku polskim sprawowana jest $\mathrm{w}$ nich głównie przez kapłanów przybywających z Polski oraz Łotyszy.

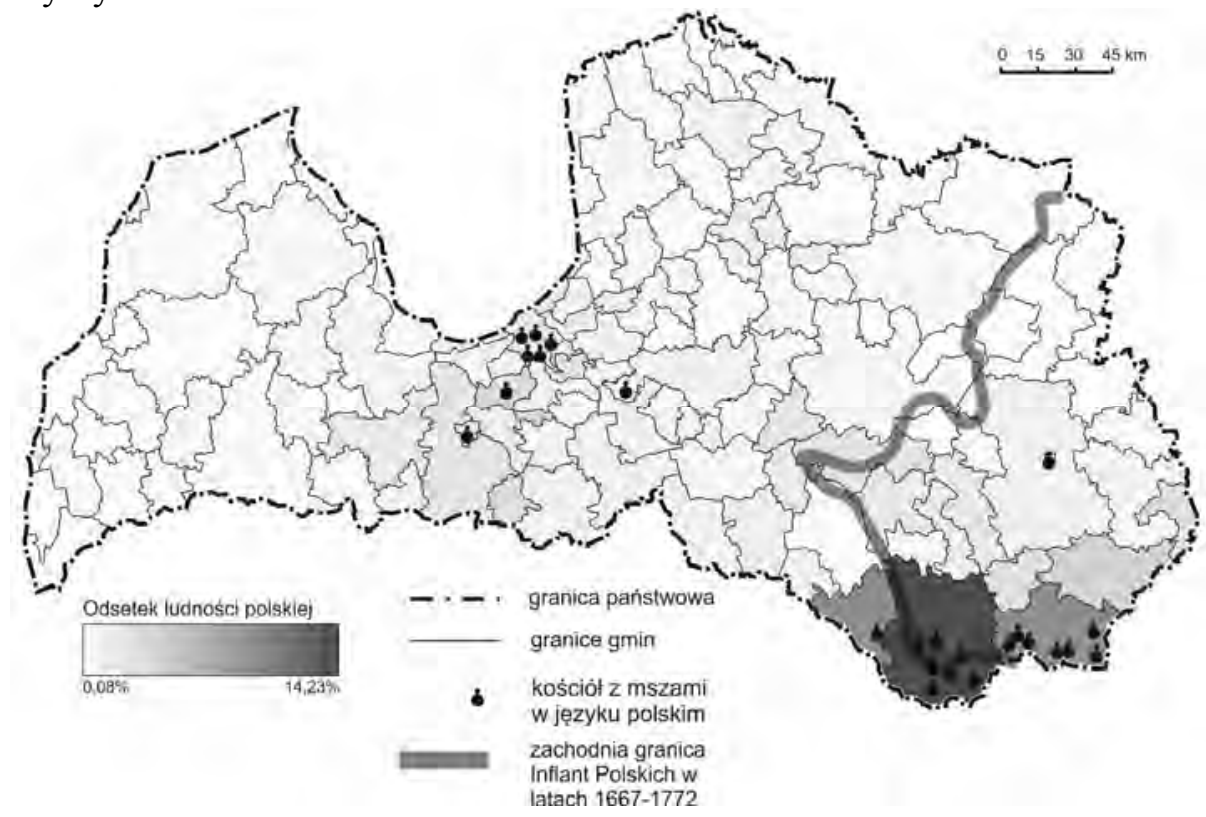

Ryc. 5. Rozmieszczenie kościołów z mszami w języku polskim w 2015 r. na tle udziału osób deklarujących narodowość polską na Łotwie podczas spisu ludności z $2011 \mathrm{r}$.

Źródło: opracowanie własne na podstawie danych z Instytutu Duszpasterstwa Emigracyjnego im. Kard. Augusta Hlonda w Poznaniu

Jak podkreślają liderzy polskich organizacji działających na Łotwie, mimo że wielkość dwóch największych skupisk Polaków na Łotwie jest podobna, to organizacje dyneburskie są dużo bardziej aktywne niż stowarzyszenia działające w Rydze. Wynika to przede wszystkim $\mathrm{z}$ wielkości i charakteru ośrodków, w których funkcjonują. Ryga jest dużo większym miastem, a Polacy w niej mieszkający są bardziej rozproszeni. $Z$ kolei Dyneburg, mimo że jest drugim co do wielkości miastem Łotwy, to znacznie ustępuje stolicy pod względem liczby mieszkańców. Dodatkowo stanowi od wieków centrum kulturalne mniejszości narodowych, w tym również ludności polskiej. Polacy w mieście stanowią ok. 15\% mieszkańców i są dodatkowo wspierani przez ludność polską zamieszkującą region Łatgalii. Uwarunkowania te wpływają na zróżnicowanie aktywności obu skupisk ludności polskiej. 
Warto wspomnieć, że obok oficjalnie zarejestrowanych organizacji, na Łotwie działa również szereg polskich zespołów artystycznych, w tym taneczne, muzyczne i teatralne, a także grupy sportowe; funkcjonują również polskie media. W 1989 r. zaczęło ukazywać się pierwsze polskie pismo „Polak na Łotwie" - kwartalnik ZPŁ. Pismo komentuje bieżące wydarzenia z życia Polaków na Łotwie, opisuje spotkania polskich i łotewskich polityków, a także wiele uwagi poświęca przypomnieniu ważnych wydarzeń historycznych z udziałem Polaków, mających miejsce na Łotwie. W kraju nadawane są również trzy polskie audycje radiowe - „Nasz Głos” w czwartym Programie Radia Łotewskiego, „Polskofalówka” i „Głos Młodych Polaków” w lokalnym Radiu Alise w Dyneburgu. Łatgalska telewizja łotewska emituje również dwa polskie programy „Akcenty Polskie” oraz „Na Falach Daugawy”. Polskie audycje radiowe i programy telewizyjne zaczęły przeżywać poważny kryzys finansowy po 1 stycznia 2012 r., kiedy w Polsce środki na wsparcie Polaków za granicą przekazano z Senatu do MSZ.

\section{Podsumowanie}

Ogromnym problemem Polaków na Łotwie jest ich postrzeganie jako Rosjan, gdyż posługują się głównie językiem rosyjskim. Mimo to zachowali oni polską świadomość narodową, a cechą wyróżniającą ich spośród innych mniejszości jest religia katolicka. Polacy na Łotwie sporadycznie wchodzą w konflikty z Łotyszami oraz innymi mniejszościami narodowymi, dzięki czemu uchodzą za wzorcowy przykład integracji mniejszości narodowej w społeczeństwie łotewskim. Postępująca integracja Polaków przyspiesza jednak procesy asymilacyjne i w konsekwencji prowadzi do zmniejszania się liczebności oraz aktywności mniejszości polskiej.

\section{Literatura}

Albin J., 1993, Polski Ruch Narodowy na Łotwie w latach 1919-1940, Wrocław.

Biernat T., 2003, Być Polakiem na Łotwie. Świat życia codziennego, Torun.

Biesiadowska B., 2004, Polska prasa na Łotwie i jej rola $w$ kreowaniu tożsamości narodowej, [w:] Kuczyński A., Michalska M. (red.), Kultura i świadomość etniczna Polaków na Wschodzie, Wrocław, s. 325-331.

Boroń P., 2011, Ryska Średnia Szkoła Polska im. I. Kozakiewicz, Ryga.

Budyta-Budzyńska M., 2010, Socjologia narodu i konfliktów etnicznych, Warszawa.

Byczkowski J., 1992, Z dziejów Polaków na Łotwie w XX wieku, [w:] Kubiak H., Paleczny T., Rokicki J., Wawrykiewicz M. (red.), Mniejszości polskie i Polonia w ZSRR, Wrocław-Warszawa-Kraków, s. 351-362. 
Durejko A., 2001, Polskie życie kulturalne i literackie na Łotwie w XX wieku, Wrocław.

Eberhardt P., 1996, Między Rosja a Niemcami. Przemiany narodowościowe w Europie Środkowo-Wschodniej wXX w., Warszawa.

Eberhardt P., 1998a, Polska ludność kresowa. Rodowód, liczebność i rozmieszczenie, Warszawa.

Eberhardt P., 1998b, Problematyka narodowościowa Lotwy, Warszawa.

Eberhardt P., 2012, Przemiany narodowościowe w Łatgalii, „Sprawy Narodowościowe”, 40 , s. $63-85$.

Frąckowiak-Karczewska K., 1993, Z dziejów szkolnictwa polskiego na Łotwie, [w:] Walewander E. (red.), Polacy na Łotwie, Lublin, s. 309-320.

Fuszara M., 2009, Polacy nad Dźwina - podobni czy odmienni od Polonii w innych krajach?, [w:] Kurczewski J., Małgorzata F. (red.), Polacy nad Dźwina, Warszawa, s. $177-202$.

Gawkowska A., 2009, Polacy w parafiach (głównie rzymskokatolickich) w Daugavpils, [w:] Kurczewski J., Małgorzata F. (red.), Polacy nad Dźwina, Warszawa, s. 83-100.

Grędzik A., 1999, Szkolnictwo polskie na Łotwie 1989-1998, „Przegląd Polonijny”, 2, s. 43-65.

Janusz G., 2011, Ochrona praw mniejszości narodowych w Europie, Lublin.

Jędrzejewski K., 1999, Odrodzenie życia narodowego Polaków w Łotwie w latach 19891996, „Przegląd Polonijny”, 4, s. 89-106.

Jēkabsons E., 1993, Stosunki polsko-łotewskie na przestrzeni dziejów, [w:] Walewander E. (red.), Polacy na Łotwie, Lublin, s. 23-44.

Jēkabsons Ē., 1994a, Zarys historii stosunków polsko-łotewskich, [w:] Sozański J., Szklennik R. (red.), Kultura polska na Łotwie, Ryga, s. 7-9.

Jēkabsons Ē., 1994b, Życie kulturalne Polaków w Republice Łotewskiej (1918-1940), [w:] Sozański J., Szklennik R. (red.), Kultura polska na Łotwie, Ryga, s. 188-199.

Jēkabsons E. E., 2013, Polska mniejszość narodowa na Łotwie. Krótka charakterystyka i zarys działalności, „Wiadomości Historyczne”, 4, s. 21-26.

Kowalski M., 2013, Ludność polska w wieloetnicznych regionach Litwy, Łotwy i Białorusi, [w:] Rykała A. (red.), Przestrzenny wymiar wielokulturowego dziedzictwa „Studia z Geografii Politycznej i Historycznej”, 2, s. 205-236.

Kurczewski J., 2009, Polacy nad Dźwina - wyniki badań ankietowych 2007 roku, [w:] Kurczewski J., Fuszara M. (red.), Polacy nad Dźwina, Warszawa, s. 17-60.

Kurczewski J., Fuszara M., 2009, Polacy nad Dźwina, Warszawa.

Leśniewska K., 2014, Współczesna sytuacja mniejszości polskiej na Łotwie - ujęcie geograficzno-polityczne, „Acta Universitatis Lodzensis, Folia Geographica Socio-Oeconomica", 17, s. 235-250.

Leśniewska-Napierała K., 2015, Geograficzno-polityczne uwarunkowania sytuacji mniejszości polskiej na Litwie i Łotwie po 1990 roku, Łódź.

Łach W.B., 2011, Rozbieżności w stosunkach polsko-łotewskich po I wojnie światowej i ich wojskowo-polityczne następstwa, „Przegląd Wschodnioeuropejski”, 2, s. 135-150.

Łossowski P., 1990a, Łotwa nasz sasiad. Stosunki polsko-łotewskie w latach 1918-1939, Warszawa.

Łossowski P., 1990b, Tragedia państw battyckich 1939-1941, Warszawa. 
Makowski G., 2009, Polskie organizacje w Daugavpils, [w:] Kurczewski J., Fuszara M. (red.), Polacy nad Dźwina, Warszawa, s. 123-152.

Németh Á., 2013, Ethnic diversity and its spatial change in Latvia, 1897-2011, „PostSoviet Affairs", 29 (5), s. 404-438.

Németh Á., Léphaft Á., 2013, Ethnic structure and minority rights in the interwar and post-Soviet Estonia and Latvia: http://www.tankonyvtar.hu/hu/tartalom/tamop422b/ 2010-0029_kotet_19_017_19/017_19.pdf [dostęp 15.05.2016].

Paluszyński T., 1999, Walka o niepodległość Łotwy 1914-1921, Warszawa.

Paluszyński T., 2011, Walka o niepodległość Estonii. Lotwy i Polski. Porównanie, [w:] Adamczyk A., Rogut D. (red.), Polska i kraje battyckie. Wybrane problemy z dziejów Polski i krajów battyckich w XX wieku, Piotrków Trybunalski, s. 21-54.

Runiewicz-Jasińska R., 2003, Oświata polska w niepodległej Litwie, Lotwie i Estonii w latach 1991-2001, Wilno.

Stanisławska M., 2003, Szkolnictwo polskie na Łotwie, „Sprawy Wschodnie”, 1 (2), s. $65-76$.

Stradiņš J., Grosvalds I., 1994, Nauka polska a Łotwa, [w:] Sozański J., Szklennik R. (red.), Kultura polska na Łotwie, Ryga, s. 31-44.

Stradiņš, J., Szymańska M., 1994, Udział Polaków w rozwoju kultury na Łotwie, [w:] Sozański J., Szklennik R. (red.), Kultura polska na Łotwie, Ryga, s. 24-30.

Urlińska M.M., 2007, Szkoła polska na obczyźnie wobec dylematów tożsamościowych na przykładzie szkoły polskiej w Rydze, Toruń.

Užule S., 2003, Łatgalia na tle innych regionów Łotwy, [w:] Paluszyński T., Navickas T., Marcinkowska L., Łotwa, wczoraj, dziś i jutro - materiaty pokonferencyjne, Poznań, s. $103-106$.

\section{Organizational activity of Polish minority in Latvia (former Polish Livonia)}

\section{Summary}

Polish Livonia is the most culturally diverse region in Latvia. Many organizations which work here, they try to uphold the traditions of national minorities. In the article discusses the organizational activities of the Polish minority in Latgale region. The study also shows the educational activities of Poles in the Republic of Latvia. In the research used a sociological method of in-depth interviews with the leaders of Polish organizations. The purpose of the interviews was to know the opinion of the most active and the most competent group of activists.

Keywords: national minority, Poles, education, organizational activity.

Katarzyna Leśniewska-Napierała, dr Uniwersytet Łódzki, Wydział Nauk Geograficznych, Instytut Zagospodarowania Środowiska i Polityki Przestrzennej, 90-142 Łódź, ul. Kopcińskiego 31 